\title{
Islamic Financing Instrument Under Indonesia Positive Law
}

\author{
Supardan Mansyur \\ Fakultas Hukum Universitas Mataram \\ Jl. Majapahit No. 62 Mataram \\ Telp (0370) 633035, Fax 626954 \\ Email : \\ Usman \\ Fakultas Hukum Universitas Mataram \\ Jl. Majapahit No. 62 Mataram \\ Telp (0370) 633035, Fax 626954 \\ Email : \\ Lalu Sabardi \\ Fakultas Hukum Universitas Mataram \\ Jl. Majapahit No. 62 Mataram \\ Telp (0370) 633035, Fax 626954 \\ Email :
}

\begin{abstract}
Islam governs all aspects of human life. It is not regulate the human relation to Allah only but also between human each other, among other economy like financing comply with shari'ah. The issues are: (1) how is the regulation of financing comply with shari'ah regulated ini positive law in Indonesia; and (2) handicap faced in its application in Indonesia. The purposes of this research are to know: (1) its regulation on positive law, and (2) its handicap in its application Indonesia. This study is a normative study, that is analyzed rules and principles regarding Islamic financing as stipulated in Indonesia positive law. Approach in this study is statute approach and conceptual approach. Its results are: (1) Islamic financing in Indonesia is regulated in various rules and regulation and their implementation strengthening its existing in positive law in Indonesia as Act No.7/1992 on Banking (amended by Act No. 10/1998), Act No. 23/ 1998 on Indonesia Bank (amended by Act No. 3/2004), and Act No. 21/ 2008 on Islamic banking, particular to Shari'ah Capital Market its regulation is regulated by OJK Decision and DSN-MUI Fatwas; (2) murabahah based financing) dominating all financing of Indonesian banking industry is considered as the cause of Islamic Banking avoided to use Mudharabah and Musharakah is their higher risk.
\end{abstract}

Keywords : Islamic law, financing instrument, Indonesian law

\section{INTRODUCTION}

In this recent decade has arisen Islamic Banks in some include Indonesia. The appearance of these are supported by the willing from some Muslim communities to reformulate and manage their social, economy activities, particularly in interest-free financing in accordance with the Allah prohibition on usury (interest). 
The increasing of this need is indicated by functioning of the Islamic Banking System without interest-rate mechanism of the financial sector operation. ${ }^{1}$ Islamic system based on the norms originating from al-Qur'an and Sunnahhas its paradigm itself on economic relation. Shari'ah, among other, states that rules related to the human resources, ownership, production, consumption, distribution income and wealth, ${ }^{2}$ in which their core are the mechanism of allocation of the financial resources. ${ }^{3}$

In the international level Islamic finance has achieved the rapid growth with the very quick growth of financial segment in GCC countries, Malaysia, Africa countries like South Africa, Nigeria, Kenya, and Ivory Coast, inAsia like Singapura and Indonesia; and in the other regionsnamely Luxembourg, United Kingdom and German. ${ }^{4}$ The Islamic finance assets has growth at two digit levels during the past Aset aset The financeShari'ahbertumbuh pada tingatan dua digit during the last decade, approximately US\$200 billion in 2003, predicted till about US\$1.8 trilliun in the end of 2013 (Ernst \& Young 2014; IFSB 2014; and Oliver Wyman 2009). ${ }^{5}$ The Islamic finance market are in approximately $\$ 1.81$ trilliun in the 2014 disclosed assets by the (fully comply with Shari'ah as well as the assets with Shari'ah windows) including commercial bank, funds, sukuk, takaful, and the other segments namely: \$1,346 billion for commercial banks, \$33.4 billion for takafuls (Islamic insurance), \$295 billion formain Sukuk (receivables (bonds)), $\$ 56$ billiun in funds (financing) (funds), and $\$ 84$ billion for the other financial activities. Islamic financing Industrys has been undergone extremely growth during the last years and recorded multiplicity annual growth level, from 17.3\% between 2009 and 2014. (IFSB Stability Report, 2015). Total assets of Islamic Banking are predicted to $\$ 2,610$ billion in $2020 .^{6}$

In Indonesia this development are accommodated by inducing the dual banking systemin Indonesia, 1986, namely a system permitting conventional and Islamic Banks operating side by side. In the same time was founded the first Islamic Banks, namely "Bank Muamalat Indonesia (BMI)”. This Dual Banking SystemSistem has been applied actually since 1998 when the Banking Act 11992 was amended by the Act No.10/1998. This act both give the

1 Saad Abdul Sattar Alharran.(1996). Islamic Finance, Pertnership Financing, Publications, Malaysia: Pelanduk, p. 1

2 Iqbal Z dan A. Mirakhor.(1987). 'Islamic Banking' At Tawhid, A Qurterly Journal of Islamic Thught and Cultre, as quoted by Sattar, ibid,.p. 91

3 Sattar Op. Cit., p. 1-2.

4 Mufti Ismail Ebrahim Desai, Islamic Finance - Opportunities and Challenges, Journal of Islamcn Banking and Finance. Volume 33 Jan-Mar. 2016 No. 1, http://islamicbanking.asia/wp-content/uploads/2016/04/JanMarch-PDF.pdf, accessed on February $25^{\text {th }} 2017$ p. 86

5 Ibid.,p. 86.

$6 \quad$ Ibid., p. 87-88. 
firm legal basis for Islamic Banking as a part of national banking system, ${ }^{7}$ also give the broad opportunity for investors to found the new Islamic and Conventional Bank to open Islamic venture unit. $^{8}$

This act was followed by some implementing rules through the Decision of Indonesia Bank Administration dated 6 May 1999 on General Bank(General Bank)based on Islamic Principle, People Rura Bank (The Rural Bank (BPR), and BPR based Islamic Principle (BPRS). Under this Decision, conventional banks may carry out Islamic Banking transaction through opening the branch of Islamic banks or converting conventional banks into Islamic banks. ${ }^{9}$ And, by enacting Act Number 21Year 2008 on Islamic Baking (Perbakan Syar'ah), the legal basis for the operation of this banking more and more strong in national baking system, then the legal basis for banking operation in Indonesia increasingly strong in national banking system. Following of this Act was issued several rules and regulation in Islamic banking and financing.

In its operation, Islamic Baking has products, namely: (1) product on collecting fund, (2) product on distributing fund, and (3) product on services. Product on collecting fund consist of wadli'ah, and mudharabah; product on distributing fund consist of murabahah, salam, istishna, ijarah and ijarah muntahiabit tamlik, musyarakah, musyarakah investment, mudharabah investment, qardh loan, and others, including: Financial Market for Inter Islamic Bank (Pasar Uang Antar Bank Syariah), Sovereign Sukuk and Bond of Central Bank (Sertifikasi Bank of Indonesia Shari'ah dan Obligasi Shari'ah); and product of services including wakalah, kafalah, sharf, hawalah, rahn, and the shari'ah principle on service namely Islamic Letter of Credit (Letter of Credit Shari'ah) and Card (Kartu Payment). ${ }^{10}$

The Islamic finance forms a part of Islamic bank product, namely fund distributing by Islamic Banking. Parallel to the increasing of spirit in several economic activities whether in real or financial sectors side by side with global development of Islamic Economy, today Islamic Finance as a part of it to be a day to day issues in the world economic life. ${ }^{11}$ Indonesia with Most Moslems population (12,7\% of World Moslems population), promulgated five years strategy for Islamic finance strategy. Indonesia Authority want Indonesia Islamic Bank to dominate at least 15 percent at 2023. Islamic Banks in Indonesia Banks involve 12 fully

7 Zainul Arifin.(2009).Fundaments of Syari'ah (Islamic) Banking, revision ed., Azkia, p. 10

8 Ascarya Diana Yumanita.(2005).Islamic Bank, General Description, Center for Education and Centralizing Bank (PPSK) Bank of Indonesia, Jakarta, p. v

9 Arifin, Op.Cit., p. 10.

10 See Wiroso.(2009).Product of Syariah Bank, LPFE Usakti.

11 Religion Ministry of Republic of Indonesia.(2013). Direktor General for Islamic Community Guidance, Pocket Book on Syari'ah Banking, Religion Deapartement of Republic of Indonesia, Direktor General for Islamic Community Guidance, Direktorate of Islamic Religion Affairs and Syati'ah Guidance, p. i. 
fledged Islamic banks and 22 Islamic banking windows. In addition, there are 316 shares for 45 Islamic insurance (takaful) institutions in this country. Furthermore, there are 316share comply shari'ah, namely $60 \%$ share in Indonesia. Market of Indonesia Shari'ah share is the second largest in the South-East Asia. Government has issued its first retail sukuk in February 2009 \$144.4 milion, and sovereign Sukuk based on Ijarah principle in August 2008 with selling 7-years (IFR0001) 10-years (IFR0002), Shari'ah Bond, and allocated 6.94 trilillion IDR to Infrastructure project through issuing Sovereign Sukuk. ${ }^{12}$

\section{METHOD}

This study is a normative study, that is analyzed rules and principles regarding Islamic financing as stipulated in Indonesia positive law. Approach in this study is statute approach and conceptual approach.

\section{ANALYSIS AND DISCUSSION}

The issues risen in this article are related to the regulation of Islamic Finance including the Islamic Finance Instruments, and its handicap in their implementation.

In this article is discussed the regulations on Islamic finance in positive law and its handicap in its implementation in Indonesia.

The rules and regulations regulating or having close relation to the Islamic finance industry includes:

1. Act Number Act Number 24 Year 20087 Year 1992 on Banking;

2. Act Number Act Number 24 Year 2008 Year 1998 on Indonesia Bank;

3. Act Number 24 Year 2008 on Saving Security Institution;

4. Act Number 21 Year 2008 on Islamic Banking;

5. Act Number 19 Year 2008 on State Islamic Securities;

6. Act Number 40 Year 2014 on Insurance;

7. Act Number 8 Year 1995 on Stock Exchange.

\section{Act Number 7 Year 1992 on Banking (amended by Act Number 10 Year 1998)}

Act Number 7 Year 1992 on Banking implicitly recognizes the existence of banking organizing activities based on Shari'ah by allowing operation of banking with profit sharing

\footnotetext{
${ }^{12}$ Mufti Ismail Ebrahim Desai, "Islamic Finance - Opportunities and Challenges”, p. 88
} 
system. ${ }^{13}$ It has the important role in facilitating of creating Islamic Banking in Indonesia, namely Indonesia Muamalat Bank (Bank Mamalat Idonesia).

This act is amended by Act Number 101998 on the amendment of the Act Number 7 Year 1998 on Banking, regulating relatively enough and detail of the Islamic Banking and implicitly recognizing the existence of Islamic Banking through Article 1 paragraph 3 and 4. Article 1paragrah 3 states that General Bank is a bank performing work activities conventionally and/or based onShari'ah Principle giving services in payment traffic. And, Article 1 paragraph 4 states that the Rural Bank (Bank Perkreditan Rakyat) is a bank performing its venture activities conventionally or based onShari'ah Principle and its activities is not gives services in payment traffic.

This act states also that the kinds of venture that can be done by General Bank may be supplying financing and/or performing other activities comply with Shari'ah Principle, performing venture activitiesparticipation of capital while solve consequences of credit or the financing failure comply with Shari'ah Principle (Article 6(1)), provided that it must draw out its participation must fulfil provision stated by Bank of Indonesia (Article 7 point c); in giving credit or the financecomply with Shari'ah Principle, General Bank shall be has conviction based on the depth analysis of conviction and capability as well as capability of debtor customers to pay their debt or turn back the finance in accordance with their agreement (Article 8 (1)), and shall has applied the crediet and finance guidance comply with Shari'ah Principle, in accordance with provision stated by Bank of Indonesia (Article 8 (2)).

In relation to the ventures of The Rural Bank, Article 13 point c. states that the Rural Bank supplying financing and putting fund comply with Shari'ah Principle, in accordance with provision stated by Bank of Indonesia.

\section{Act Number 23 Year 1998 onBank of Indonesia (Amended by Act Number 3 Year 2004)}

Provision of Act Number 23 Year 1998 onBank of Indonesia related to the Islamic finance is stated in Article 10 and Article 11. Article 10 states that determination of policy and control apply also to the bank applying Shari'ah Principle (Article 10 (2)), which implementation is determined by The Regulation of Bank of Indonesia.

Act Number 3 Year 2004 onthe Amendment of Act Number 23 Year 1999 onBank of Indonesia amend provision Article 10 (1) by eliminating phrase in point a stating that "lays

13 Muhammad Syafii Antonio.(2001). Syari'ah (Islamic) Bank From Theory to Practic, Jakarta: Gema Insani, p.26 
down monetary targets by paying attention target inflation rate that it has stated", so Article 10 (1) states:

In determining and implementing monetary policy stated in Article 8 point a, Bank of Indonesia may: (a) lays down monetary targets by paying attention target of inflation rate.

Next, it is stated also that: Bank of Indonesia may give credit or financecomply with Shari'ah Principle for maximal 90 (ninety) days to the Bank to solve the short-term of such Bank (Article $11(1)$ ); the implementation the or this financemust be assured by the acceptance bank with high quality guarantee and easy to be liquefied with the value same as the amount of its credit or the accepted finance (Article 11 (2)); the implementation of provision in paragraph (1) and paragraph (2) are determined by the Regulation of Bank of Indonesia ((Article $11(3))$.

\section{Act of Republic of Indonesia Number 24 Year 2004 OnSaving Bailsman Institution}

This act obligate to every bank performing venture activities in the territory of Republic of Indonesia to be participant of The Avalist (Article 8 (1), except Village Credit Board (Badan Kredit Desa) (Article 8 (2). Certainly the obligation to be participant of the Avalist include Islamic Bank, for it is not excepted by Article 8 as laid down to the Village Credit Board.

\section{Act of Republic of Indonesia Number 21 Year 2008 onThe Islamic Banking}

This act differentiates banks venture activities comply with Shari'ah Principle to be three kinds, General Islamic Bank, Islamic Credit Bank, and Islamic Ventures Unit.

The venture activities that can be done by Shari'ah General Bank includes: (a) to collect fund in the Saving form as Demand Deposit, Saving, or the other forms similar to it based on Wadi'ah akad or the other akad not contradict to the Shari'ah Principle; (b) to collect fund in the form of investment including deposit, saving, or the other forms similar to them based on Mudharabah akad or the other akad not contradict to Shari'ah Principle; (c) to distribute the profit sharing financing based on mudharabah, akad musyarakah, or the other akad not contradict to the Shari'ah Principle; (d) to distribute financingbased on murabahah akad, Salam akad, Istishna akad', or the other akad not contradict to Shari'ah Principle; (e) to distribute financingbased on qardh or the other akad not contradict to Shari'ah Principle; (f) to distribute financing of the hiringmoveable or immoveable goods to the customersbased on Ijarah akad and/or hire purchase in the form of ijarah muntahiya bittamlik or the other akad 
not contradict to Shari'ah Principle; (g) to perform debt transferring based on Hawalah akad or the other akad not contradict to Shari'ah Principle; (h) to perform the debt card venture and/or financing cardcomply with Shari'ah Principle; (i) to buy, sale, or secure with it risk it self securitiesfor the third party issued based on the real transactions comply with Shari'ah Principle, among other, Ijarah, musyarakah, mudharabah, murabahah, kafalah, or hawalahakad; (j) to buy securities comply with Shari'ah Principle issued and/or Bank of Indonesia; (k) accept payment of claims for securities and to perform calculation with the third party or inter of the third parties comply with Shari'ah Principle; (1) to perform deposit on behalf ofthe other parties based on an akad comply with Shari'ah Principle; (m) to make available places to save goods and securities comply with Shari'ah Principle; (n) to transfer money, whether on own behalf of or on behalf of customercomply with Shari'ah Principle; (o) to perform function as Trustee based on Wakalah akad; (p) give fasilities letter of credit or guarantee bank comply with Shari'ah Principle; and (q) performing other activities are normallyperformed in the banking field and in the social not contradict to Shari'ah Principle and in accordance with provision of the Rules and regulations (under Article 19 (1)). In addition to, Shari'ah General Bank may perform activities: (a) foreign currency comply with Shari'ah Principle; (b) participation of capital to Shari'ah General Bank or financial institutions performing venture activities comply with Shari'ah Principle; (c) participation of capital sementara to solve consequences of failing of the financing comply with Shari'ah Principle, provided it must draw out its participation; (d) acting as the founder and management of the pension fund comply with Shari'ah Principle; (e) in capital marketas far not contradict to Shari'ah Principle and provisions the rules and regulations in ; (f) the running of venture activitiesor product of bank comply with Shari'ah Principle by using electric devices; (g) issuing, offering, and trading short-term securities comply with Shari'ah Principle, whether directly or indirectly through money market; (h) issuing, offering, and trading securitieslong-term comply with Shari'ah Principle, whether directly or indirectly through capital market; and (i) to make available productor to perform other venture activities of the Shari'ah General Bank comply with Shari'ah Principle (Article 20 (1)).

For UUS venture activities wich may be performed includes: (a) to collect fund in the Saving form including Demand Deposit, Saving, or the other forms similar to them based on Wadi'ah or the other akad not contradict to the Shari'ah Principle; (b) to collect fund in the form of investment including Deposit, the Saving, or the other forms similar to them based on Mudharabah akad or the other akad not contradict to Shari'ah Principle; (c) to distribute financing of profit sharing based on Mudharabah, musyarakah akad, or akad not contradict 
to Shari'ah Principle; (d) to distribute financingbased on murabahah, Salam, Istishna akad', or The other akad not contradict to Shari'ah Principle; (e) to distribute financingbased on akad qardh or the other akad not contradict to Shari'ah Principle; (f) to distribute financing of the hiringmoveable or immoveable goods to customersbased on Ijarah akad and/or hire purchase in the form of ijarah muntahiya bittamlik or the other akad not contradict to Shari'ah Principle; (g) to perform debt transferring based on Hawalah akad or the other akad not contradict to Shari'ah Principle; $h$. to perform the debt card venture and/or financing cardcomply with Shari'ah Principle; (i) to buy and sale securitiesfor the third party issued based on the real transactions comply with Shari'ah Principle, among other, Ijarah, musyarakah, mudharabah, murabahah, kafalah, or hawalah akad; (j) to buy securities comply with Shari'ah Principle issued by Government and/or Bank of Indonesia; (k) to accept payment of claim for securities and to perform calculation with the third party or of the third parties eac other comply with Shari'ah Principle; (l) to make available places to save goods and securities comply with Shari'ah Principle; m. to transfer money, whether on own behalf of or on behalf of customer comply with Shari'ah Principle; n. give facilities letter of credit or guarantee bank comply with Shari'ah Principle; and o. performing other activities normallyperformed in the banking field and in the social field not contradict to Shari'ah Principle and in accordance with provision of the rules and regulations (Under Article 19 (2)). UUS may also perform venture activities (a) foreign currency comply with Shari'ah Principle; b. in capital market as far as not contradict to Shari'ah Principle and provisions of the rules and regulations in the capital market field; (c) temporary capital participation to solve the consequences of the financing failure comply with Shari'ah Principle, provided it must draw out its participation; (d) the running venture activities or product of bank comply with Shari'ah Principle by using electric devices; (e) issuing, offering, and trading short-term securities comply with Shari'ah Principle whether directly or indirectly through mney market; and (f) to make available productor to perform the other venture activities of the Shari'ah General Bank comply with Shari'ah Principle. (3) venture activitiesas inteded in paragraph (1) and paragraph (2) must fulfil provision stated by Bank of Indonesia and provisions of the rules and regulations (Article 20 (2)).

Under Article 21 the venture activities of the Islamic Rural Bankincludes: a. to collect fund from people in the form: (1) the Saving including the deposit or similar to them based on Wadi'ah akad or the other akad not contradict to Shari'ah Principle; dan (2) Investment including Deposit or the Saving or the other forms similar to them based on Mudharabah 
akad or the other akad not contradict to Shari'ah Principle; b. to distribute fund to eople in the form: 1. The loss sharing finance based on Mudharabah akad or musyarakah; 2. The financebased on murabahah akad, salam, or istishna'; 3. The financebased on akad qardh; 4. The financethe hiringmoveable or immoveable goods to customersbased on Ijarah akad or hire purchase in the form of ijarah muntahiya bittamlik; and 5. debt transferring based on Hawalah akad; c. to put the fund in the other Islamic Banklain in the form of deposit based on Wadi'ah akad or investment based on Mudharabah akad and/or the other akad not contradict to Shari'ah Principle; d. to transfer money, whether on own behalf of or on behalf of customerthrough bank accoun the Islamic Rural Finance existing in Shari'ah General Bank, Convensional General Bank, and UUS; and e. to make available productor to perform venture activities of the other Islamic Bank existing in accordance with Shari'ah Principle based on approval of Bank of Indonesia. and in Article 22 is stated that every to perform venture activities to collect fund in the Saving form or Investment comply with Shari'ah Principlewithout permit prior to from Bank of Indonesia, except regulated in the other act.

\section{Act of Republic of Indonesia Number 19 Year 2008 onSovereign Islamic Sukuk (Surat Berharga Syari'ahNegara)}

Under this act Souvereign Sukuk - Surat Berharga Syari'ahNegara, hereafter refer to SBSN, or may be called as Sovereign Sukuk, is state securities issued comply with Shari'ah Principle, as an evidence for participation to SBSN asset, whether in rupiah or foreign currency (Article 1.1). SBSN may be issued in the form of warkat orwithout warkat (Article 2 (1), dan may be traded or not to be traded di secondary market (Article 2 (2)).

SBSN may including: a. SBSN Ijarah, issued based on Ijarah akad; b. SBSN Mudarabah, issued based on akad Mudarabah; c. SBSN Musyarakah, issued based on musyarakah akad; d. SBSN Istishna', issued based on Istishna akad'; e. SBSN issued based on the other akad not contradict to Shari'ah Principle; and f. SBSN issued based on kombinasi dari dua or lebih dari akad as inteded pada point a sampai with point e. (Article 3), and be issued with the purpose to fund the State Budget include to fund project of development (Article 4). The competency to issue SBSN is held by Government (Article 5 (1)), and implemented by Minister (Article 5 (2)).

The issuance of SBSN may be implementeddirectlyby Government or through the venturesan Penerbit SBSN (Article 6 (1)), includes all kinds SBSN as stated in Article 3 (Article 6 (2)). The issuance of SBSN conducted through the company of the issuer of SBSN laid down by Minister (Article 6 (3)). The issuance of SBSN to the purpose as stated in 
Article 4, Ministerprior to coordinate with Bank of Indonesia (Article 7 (1)), dan issuance of SBSN in the financeproject, Minister coordinate with minister in the planning field of national development (Article 7 (2)).

\section{Act of Republic of Indonesia Number 40 Year 2014 On Insurances}

Beside of regulating conventional insurance, this act regulates Islamic Insurance (Insurance Syariah) too. Under this act Islamic Insurance is aset of agreements between Islamic Insurance Company and the the police holders, in managing the contribution comply with Shari'ah Principle to help and protect each ather by: a. giving compentaion to the parties or holders for losses, damages, or the costs may araising, or or the losses of profit, legal responsibility to the third party might be sufferred by the parties or police holders for the evenement; or b. give payment based on the death of the parties as well as or payment based on the life of the parties with the benefit with the rate as provided and/or based on the result of fund management (Article 1 point 2).Shari'ah Principleas syari'ah insurance basis formulated as Islamic lergal principle in the venture activities of insurances based on fatwa issued by the institution having the authority in providing fatwa in the Syari'ahfield (Article 1 butir 4). In addition to this act regulates various matters related to the ventures of insurance.

The most important of them are:

Under Article 3 (1) tgis act the general insurance enterprises may run: a. the ventures of Syariah general insurance, including the ventures of the health insurance field comply with Shari'ah Principle and the ventures of the accident insurance field comply with Shari'ah Principle; and b. The ventures of Syariah Reinsurance for risk of the other Syari'ah general insurance entrepises. Next, paragraph (2) states that the enterprise of Syrai'ah life insurance may operate the ventures of Syrai'ah life insurance include field the ventures anuitas comply with Shari'ah Principle only, the ventures of the health insurance field comply with Shari'ah Principle, and the ventures of the accident insurance field comply with Shari'ah Principle, dan the entreprise of reIslamic Insurance hanya may the running The ventures Syariah Reinsurance (aparagraph (3)).

The venturesthe geeral insurance Syariah dan the ventures Syrai'ah life insurance may be extended in accordance with the community need (Article 5 (1), and may including the increasing of benefit with the rate based on the result of fund management (Article 5 (2)). 


\section{Act Number 8 Year 1995 on Capital Market (UUPM)}

Capital Market is a very important segment in Shari'ah financial market in Indonesiato promote.Capital marketmay help to give capital for helping Government budget in building infrastructure or the development of the entreprises in extending their ventures. ${ }^{14}$

Market Shari'ah Capital in Indonesia develop gradually in this last decades to be the larger part of the domestic financial system. ${ }^{15}$ Contrast to te the conventional market capital, Shari'ah market capital is emeinence to the conventional capital market, namely the conventional investors only who may invest to tha conventional market capital, on the contrary in Syariah market capital both the conventional investorsand who have Syari'ah profession may do it. As a consequence, the scope of investors in Syariah market capital more extend than the investros in conventional market capital.$^{16}$

Market Shari'ah Capital is not regulated yet as an it self standing istitution in Inonedian positive law.Capital marketregulated in the Act Number 8 Year 1995 on Capital Market(UUPM) is Conventional Capital Market. The Operation of Syari'ahital Market based on the Regulation Financial Service Authority (OJK) ad fatwas Syari'ah Board - Indonesian Ulama Asembly (MUI).

This Regulations from Financial Service Authority (OJK) and fatwas of Syari'ah Board - Indonesian Ulama Asembly (MUI) to be the operational basis for Shari'ah market capital, and has been followed by the entreprenerurs performing venture activities with Shari'ah Principle in capital market. Thus, Shari'ah market capital having positive legal basis through customary law. Furthermore these regulations are strengthened by implied recognition in Indonsian legal order through the Act Number 19 Year 2008 on the issuance of Sovereign Sukuk (SBSN). This implied recognition may be found also in the Act Number 21 Year 2008 onShari'ah Banking . Article 19 paragraph (1) point (h), this Act states that Shari'ah General Bank may perform venture activities in issuing, offering, and trading securitieslong-term comply with Shari'ah Principle, whether directly or indirectly through capital market. And, paragraph (3) states that UUS beside of performig venture activities as stated in Article 19 paragraph (2), it may also perform venture activities in: (a) foreign

14 Standing Committee for Economic and Commercial Cooperation of the Organization of Islamic Organization, (Comcec), Diversification of Islamic Financial Instruments, op. cit., p. 55.

15 (Standing Committee for Economic and Commercial Cooperation of the Organization of Islamic Organization, (Comcec), Diversification of Islamic Financial Instruments, op. cit., p. 56

16 OJK, INDUSTRI JASA FINANCIAL SYARIAH, http://www.ojk.go.id/id/kanal/banking/data-danstatistik/booklet-banking-indonesia/Documents/booklet_2014_opt 1395931938.pdf, $\quad$ download 14 November 2017 at 5.45 WITA., p. 75. 
currency comply with Shari'ah Principle; b. capital marketas far not contradict to Shari'ah Principle and provisions of the rules and regulations in the capital market field.

Fatwa on capital market, indeed, is compeletely enough, even it has been issued since Year 2001. ${ }^{17}$ The most complete Fatwa on Syariah market capital is fatwa DSN-MUI Number 80 on the Implementation of Shari'ah Principle in the Mechanism of Securities Trading with Equities character in The Regular Market of Stock Exchange. The core of this fatwa among other are: ${ }^{18}$

1. Transactions of share in capital marketin accordance with Shari'ah Principle if fulfil two conditions,namely: a. perform transactions of share belong to Syari'ah Securities List (DES); dan b. do npt perform transactionscontrary to Shari'ah Principle.

2. Qabdh Hukmi in transactions of share. There is an error impression if transactions use $\mathrm{T}+3$ system or the process of settlement of securities transaction in Stock Exchange may be completed after three days may cause the syar'i charcter to be achieved. For this error the fatwa states that when an investor has bought the share and its transaction has been stated complete, he may resale it althoughbefore three days, the share he has bought is complete, and its ownership has been transferred although administratively des not achieve $\mathrm{T}+3$ yet, it is a legally ownership concept(qabdh hukmi).

3. Transactions System of Continuous Auction in accordance with this Bai al Musawammah Fatwa clarifies that the trade system in Stock Exchange Indonesia using Continuous Auction or the contonuous auction in accordance with Shari'ah Principle. The use of thi system to avoid misunderstanding of the parties related to the compatbilty with Shari'ah Principle. Theis Fatwa answers that this transaction belong to Bai $\mathrm{Al}$ Musawammah or transactions at aiming to find the effective price and no obligation to inform the seller on this price. In implementation Shari'ah Principle in capital market, the parties involved in Syariah market capital (include Stock Exchange Indonesia) not only use te fatwa as the only reference as fatwa has no binding legal effect. The involved remains must refer to the positive legal basis namely UUPM and The Regulationsof OJK.

The Regulation of Financial Service Authority Number 15/Pojk.04/2015 on the Implementation of Shari'ah Principle in capital marketgive references on the way must be 
fulfilled by Shari'ah market capital in performing the Shari'ah venture activities. Thess references include: the terms of Shari'ah ventures in Capital market, prohibitions related to te Shari'ah venture activities in Capital market, the parties who may perform the ventures in Capital market.

\section{Suvervision Board, Pelaporan, dan sanksi.}

The Regulation defines in capital market as Syari'ah venture activities in capital marketis venture activities related to the general offering in Syariah securities, sale Syariah securities, management of Syari'ahinvestment in Capital market, and Emiten or public enterprise related to Syariah securities it issued (Article 1 butir 4).

Inperforming venture activitiesShari'ah ituShari'ah market capital in accordance with provision Article 2 prohibits to perform: (1) venture activitiesand the types the ventures contrary to Shari'ah Principle in Capital market; (2) transactionscontrary to Shari'ah Principle in Capital market. Next is stated that the parties may performthe Syariah venture activities.In capital market: a. The party stating its venture activitiesand the types of the ventures, and/or how to manage it, and/or service he given comply with Shari'ah Principle in Capital market. b. The party do not stating its venture activitiesand the types of ventures, and/or and the way to manage it, and/or services he given comply with Shari'ah Principle in Capital market, yet the parties: 1. have unit of Syari'ahventures; 2. are the Investment Manager performing venture activitiesmanagement of syari'ah investment; 3 . are the Custodian of syari'ah investment; 4. A part of activities operational from the parties ventures are performed comply with Shari'ah Principle in Capital market; and/or 5. give th other Syari'ah services. c. the parties do not stating the venture activitiesand the types of ventures, and/or the way they mange it, and/or serivices they given comply with Shari'ah Principle in Capital market, yet issuing Syariah securities and/or have the role in helping the issuance of Syariah securities in capital market(Article 4).

In addition to every party performing Syari'ah venture activities in capital market is obligated to compy with Shari'ah Principle in capital marketas provided in this Regulation of Financial Service Authority an the Rules and regulations lain in the capital market sector (Article 6). Likewise every party performing Syariah venture activities in capital marketas stated in Article 4 point a dimust: a. states in statute or similar document that its venture activities to be performed comply with Shari'ah Principle in Capital market; and b. have Syari'ah Controlling Board (Article 7), and every party performing Syariah venture activities in capital marketas stated in Article 4 point b must: a. have Syari'ah Controlling Board, untuk 
Investment Manager performing the venture activitiesmanagement of syari'ah Investment; or b. have Syari'ah Controlling Board or at least 1 (one) director or the person who resposible for the venture activities given the mandateby the management having enough knowledge and/or exfrience in the field of Syari'ahfinancing, for the parties performing venture activities other than the Investment Manager managing syari'ah investment (Article 8).

Supervision Board as stated in Article 7 point a and b, and Article 8 point a consist of 1 (one) member or more appointed by the Genral Meeting of share holders, the other mechanism equivalent to the Genral Meeting of share holders, or appointed by the management (Article 9 (1)), . This Syari'ah Controlling Board Member must be individual or the venture entity having ASPM lisence from the Financial Service Authority (Article 9 (2))

\section{The barriers faced in Implementing the Shari'ah financing di Indonesia}

The barriers faced the Shari'ah financing in its Implementation cannot be separated from the weaknesses had by the Shari'ah banking. Many productoffered by the Shari'ah (Islamic) banking are equal to the conventional banking. It is not good, therefore, the $100 \%$ Islamic Bank need to be made,without copying products of conventional banks by introducing the products that wholly differece with the products of the conventional banking and in accordance with hukum Islam. ${ }^{19}$ As one of financial institutions (financial institution) entering globalmarket Shari'ah Banking, certainly facing various challenges includingm: (a) fully integrated to the the global financial market as the important element of architecture and infrastructure in the Shari'ah financing by defending its charasteriti and the uniqueness of its serivices; (b) supporting guarantee and comformity equal to the deposants ad inestors given by the conventional banking ; (c) discripancy ofhuman resources; (d) the integration of important element of architecture and infrastructure in the Shari'ah financing into globalperspektive. ${ }^{20}$

The need for intergration of the the Syari'ah Banking industry into global market are motivated by its speedy growth, and begin to dvelop beyond the Moslem Countries (Muslim dominated countries). Therefore, to be importance to integrate it fully in to the global finacial

19 Syed Farhan Shah Muhammad Wajid Raza Malik Rizwan Khurshid, ISLAMIC BANKING CONTROVERSIES AND CHALLENGES, INTERDISCIPLINARY JOURNAL OF CONTEMPORARY RESEARCH IN BUSINESS COPY RIGHT @ 2012 Institute of Interdisciplinary Business Research FEBRUARY 2012 VOL 3, NO 10, http://journal-archieves15.webs.com/1018-1026.pdf, download 6 November 2017 at 6.27 WITA., ps. 1018- 1019.

20 (Standing Committee for Economic and Commercial Cooperation of the Organization of Islamic Organization, (Comcec), Diversification of Islamic Financial Instruments, http://www. kalkinma.gov.tr/Lists/Yaynlar/ Attachments/ 777/Diversification\%20 of\%20Islamic\%20 Financial\%20Instruments.pdf accessed on November $2^{\text {nd }} 2017$ at 18.42 WITA, p. 24) 
market by defending its charachteristic and uniqueness of its services. Need beplaced fully in the banking threshold and supervised intensively as to be done to the other financial institutions.

Dhani Gunawan Idhat, Direktor of Syari'ah (Islamic Banking), OJK, states that there are seven issues faced by national syri'ah so as to be developed speedily namely: (1) its mission is not compatible yet and the lack of coordination between goverment and OJK in developing Syariah banking; (2) many Syari'ah banking has no capital adequately; (3) funding structure of Syari'ah banking remain relay on the financing from the the expensive fund; (4) their products are not diversified and their services are not compatibe yet with the expectation of they community as may be seen in the faeture of Syari'ah bank are not complete as the similar produst of the convensional bank; (5) number and quality of human resouces (SDM) and the information technology lack support the development of products as well as services; (6) the community understanding and consciousness remain low to the Syari'ah bank; (7) the arrangement and controlling is remain optimal yet,"21

Generally the Indonesian Shari'ah banking on the financing is not representatve yet of the profit sharing spirit. The services domination of the Shari'ah banking having the consumptive financeincluding the debt financing products based on Murabahah, Istishna, Ijarah and Salamcontracts dominate capital financing (the equity-financing) in the Shari'ah banking instruments (based on Mudarabah dan Musharakah), the financing based on Murabahah (murabahah based financing), dominate the whole of the banking financing industry. Indondsian Banking does not chooses to use Mudharabah and Musharakahfor it risk higher than the other, ${ }^{22}$

\section{CONCLUSION}

1. The instrumen instrument of Shari'ah financing in Indonesia regulated in various rules and regulations. The Rules and regulations itu is :

a. Act Number 7 Year 1992 onPerbakan (amended by Act No. 10 tahan 1998)

b. Act Number 23 Year 1998 onBank of Indonesia (amended by Act Number 3 Year 2004)

c. Act of Republic of Indonesia Number 24 Year 2004 OnSaving Bailsman Institution

d. Act Number 21 Year 2008 onShari'ah Banking .

21 Detik Finance, 7 Barrer Making Syariah Banking to be Late to Develove in RI, https://finance.detik.com/moneter/3076959/7-hambatan-yang-buat-bank-syariah-lambat-berkembang-di-ri, accessed on November $8^{\text {th }} 2017$ at 5.55 WITA.

$22 \quad$ Ibid.,p. 56. 
e. Act of Republic of Indonesia Number.19 Year 2008 onSovereign Sukuk .

f. Act of Republic of Indonesia Number 40 Year 2014 On Insurances.

g. Act Number 8 Year 1995 on Capital Market Act regulatingConventional Capital Market. Operational basis of Shari'ah market capital based on the Regulation Financial Service Authority Number 15/Pojk.04/2015 onImplementation Shari'ah Principle in capital market and Fatwa fatwa Dewan Shari'ah Nasional - Indonesian Ulama Assembly (MUI). Financial Service AuthorityDecision and FatwasofDewan Shari'ah Nasional to be guidance followed in the implementation of yari'ah basis venture activities and may be seen as customary law in the field of Market Shari'ah Capital. This means that Shari'ah capitalmarket have positive legal basis in Indonesia through customary law.

2. The barriers faced Implementation of the Shari'ah financing

Generally the Indonesian Shari'ah banking on the financing is not representatve yet of the profit sharing spirit. The services domination of the Shari'ah banking with the consumptive finance character including the debt financing products based on Murabahah, Istishna, Ijarah and Salamcontracts dominate capital financing (the equityfinancing) in the Shari'ah banking instruments (based on Mudarabah dan Musharakah), the financing based on Murabahah (murabahah based financing), dominate the whole of the banking financing industry. Indondsian Banking does not chooses to use Mudharabah and Musharakahfor it risk higher than the other.

\section{BIBLIOGRAPHY}

\section{Books}

Saad Abdul Sattar Alharran, Saad.(1996). Islamic Finance, Pertnership Financing, Malaysia: Pelanduk.

Z., Iqbal, dan A. Mirakhor.(1987). 'Islamic Banking' At Tawhid, A Qurterly Journal of Islamic Thught and Cultre.

Zainul Arifin.(2009). Fundaments of Syari'ah (Islamic) Banking, Azkia.

Ascarya Diana Yumanita.(2005). Islamic Bank, General Description, Jakarta: Center for

Education and Centralizing Bank (PPSK) Bank of Indonesia.

Wiroso.(2009). Product of Syariah Bank, LPFE Usakti,.

Religion Ministry of Republic of Indonesia.(2103). Direktor General for Islamic Community

Guidance, Pocket Book on Syari'ah Banking, Religion Deapartement of Republic of 
Indonesia, Direktor General for Islamic Community Guidance, Direktorate of Islamic Religion Affairs and Syati'ah Guidance.

Muhammad Syafii Antonio.(2001). Syari'ah (Islamic) Bank From Theory to Practic, Jakarta: Gema Insani.

\section{Journals}

Standing Committee for Economic and Commercial Cooperation of the Organization of Islamic Organization, (Comcec), Diversification of Islamic Financial Instruments.

\section{Worldweb}

OJK, Industry of Syari'ahFinancial Services, http://www.ojk.go.id/id/kanal/banking/datadan-statistik/booklet-banking-indonesia/Documents/booklet_2014_opt_1395931938.pdf, accessed on November $14^{\text {th }} 2017$ at 5.45 WITA.

Syed Farhan Shah Muhammad Wajid Raza Malik Rizwan Khurshid, ISLAMIC BANKING CONTROVERSIES AND CHALLENGES, INTERDISCIPLINARY JOURNAL OF CONTEMPORARY RESEARCH IN BUSINESS COPY RIGHT (C) 2012 Institute of Interdisciplinary Business Research FEBRUARY 2012 VOL 3, NO 10, http://journalarchieves15.webs.com/1018-1026.pdf, accessed on November $6^{\text {th }} 2017$ at 6.27 WITA.

Standing Committee for Economic and Commercial Cooperation of the Organization of Islamic Organization, (Comcec), Diversification of Islamic Financial Instruments, http://www. kalkinma.gov.tr/Lists/Yaynlar/ Attachments/ 777/Diversification\%20 of\%20Islamic\%20 Financial\%20Instruments.pdf accessed on November $2^{\text {nd }} 2017$ at 18.42WITA.

Detik Finance, 7 Barriers Making Syari'ah Banking to be Late to Develove in RI, https://finance.detik.com/moneter/3076959/7-hambatan-yang-buat-bank-syariah-lambatberkembang-di-ri, accessed on November $8^{\text {th }} 2017$ at 5.55 WITA.

Ismail Ebrahim Desai, Mufti, "Islamic Finance - Opportunities and Challenges", Journal of Islamcn Banking and Finance. Volume 33 Jan-Mar. 2016 No. 1, http://islamicbanking.asia/wp-content/uploads/2016/04/Jan-March-PDF.pdf, accessed on February $25^{\text {th }} 2017$. 